\title{
Autophagy Agents in Clinical Trials for Cancer Therapy: A Brief Review
}

\author{
Samiha Mohsen ${ }^{1}{ }^{\mathbb{D}}$, Philip T. Sobash ${ }^{2}{ }^{\mathbb{D}}$, Ghada Fahad Algwaiz ${ }^{3}$, Noor Nasef ${ }^{4}$, Safaa Abed Al-Zeidaneen ${ }^{5}$ \\ and Nagla Abdel Karim ${ }^{6, *}$
}

check for updates

Citation: Mohsen, S.; Sobash, P.T. Algwaiz, G.F.; Nasef, N.; Al-Zeidaneen, S.A.; Karim, N.A. Autophagy Agents in Clinical Trials for Cancer Therapy: A Brief Review. Curr. Oncol. 2022, 29, 1695-1708. https://doi.org/10.3390/curronco 129030141

Received: 16 January 2022

Accepted: 1 March 2022

Published: 5 March 2022

Publisher's Note: MDPI stays neutral with regard to jurisdictional claims in published maps and institutional affiliations.

Copyright: (C) 2022 by the authors. Licensee MDPI, Basel, Switzerland. This article is an open access article distributed under the terms and conditions of the Creative Commons Attribution (CC BY) license (https:// creativecommons.org/licenses/by/ $4.0 /)$.
1 Faculty of Medicine, University of Toronto, Toronto, ON M5S 1A8, Canada; samiha.mohsen@mail.utoronto.ca 2 Department of Internal Medicine, White River Health System, Batesville, AR 72501, USA; psobash@wrmc.com 3 Department of Medicine, King Faisal Specialist Hospital and Research Center, Al Mathar Ash Shamali, Riyadh 11564, Saudi Arabia; ghada_fahad@live.com

4 College of Arts and Sciences, The Ohio State University, Columbus, OH 72501, USA; noornassef@gmail.com

5 Department of Allied Medical Science, Al-Balqa' Applied University, As-Salt 2PF8+XM, Jordan; safaa84@bau.edu.jo

6 Department of Hematology and Oncology, Medical College of Georgia, Augusta, GA 30912, USA

* Correspondence: nkarim@augusta.edu

\begin{abstract}
Autophagy has been of novel interest since it was first demonstrated to have effect in Burkitt's lymphoma. Since that time, the autophagy agents chloroquine and hydroxychloroquine have become the only FDA (Food and Drug Administration)-approved autophagy inhibitors. While not approved for cancer therapy, there are ongoing clinical trials to evaluate their safety and efficacy. Pevonedistat has emerged as a novel inhibitor through the neddylation pathway and is an autophagy activator. This paper summarizes and presents current clinical trials for hydroxychloroquine (HCQ), chloroquine (CQ), and Pevonedistat for the clinician.
\end{abstract}

Keywords: autophagy; cancer; hydroxychloroquine; chloroquine; pevonedistat; clinical trial

\section{Introduction}

Autophagy is a catabolic process by which the body cells recycle their contents and eliminate unwanted organelles [1]. It was first described by Christian de Duve in 1963 [2]. The process involves identifying and segregating the targeted cellular organelles and directing them toward lysosomes for degradation [3]. It has been recognized through numerous studies that autophagy encompasses a variety of different cellular catabolic pathways. Each pathway targets a distinct category of cellular targets and is tightly regulated by an array of regulatory proteins and enzymes [3-6].

Macroautophagy is the most widely studied form, making it of interest in modern-day research for clinicians and drug developers [3,7-11]. The process of macroautopaghy is initiated by the formation of double membrane vesicles-autophagosomes-that engulf their target proteins and organelles from the cytoplasm and after maturation fuse with lysosomes for final degradation [12]. Fusion of the late endosomes with plasma membranes is also believed to release the contents as exosomes in the extracellular matrix. Microautophagy is the second pathway. This process is less complex; however, it is equally important. During microautophagy, lysosomes engulf cytoplasmic contents directly for degradation [13]. The final pathway involves chaperone proteins that target the structures meant to be degraded, tag them, and then transport them to lysosomes. There is no membrane sequestration for those targets as in the other two pathways.

Autophagy is a potential therapeutic target for a variety of diseases and was brought to light by results of a study on endemic Burkitt's lymphoma in Africa, where remission of the disease was linked to wide administration of chloroquine [14]. Chloroquine is an antimalarial agent that was proven to be an autophagy inhibitor [15]. The drug acts by 
inhibiting the final stages of autophagy by inhibiting fusion of the late endosomes with the lysosomes. This effect results in the accumulation of late endosomes and the redirection of their contents to the extracellular space as exosomes [16].

Among all three forms, macroautophagy has been the focus of clinical research since it has been linked to numerous vital processes such as antigen presentation [17], immunity [18-20], drug resistance [21-23], exosomes secretion [24,25], apoptosis [26], inflammation [27], and oncogenesis [28]. More recently, researchers have focused on the chronological order of administration of this drug along with other antineoplastic therapy for optimization in combination therapy [29]. The hypothesis of adding these agents is to minimize cancer cell stress adaptive mechanisms and drug resistance. This paper reviews the current FDA-approved autophagy agents chloroquine and hydroxychloroquine, along with a new and novel pro-apoptotic and autophagy inducer, Pevonedistat, in current clinical trials.

\section{Materials and Methods}

In this review, we looked at clinictrials.gov with the terms "cancer" and drug names hydroxychloroquine, chloroquine, and pevonedistat. Trials were excluded that did not involve cancer treatment. Due to the heterogeneity of study type, phase, cancer type, and treatment, the studies were not evaluated cooperatively but summarily.

\section{Discussion}

\subsection{Historical Context of Autophagy Agents in Cancer}

The role of autophagy agents in cancer is somewhat controversial [30]. There are multiple mechanisms of autophagy dysregulation that may be conducive to cancer growth As stated previously, stress in the microenvironment along with reactive oxygen species (ROS) and ischemia can upregulate autophagocytic genes to promote autophagy. This process is in response to stressors in the milieu. Interestingly enough in cancer cells, despite their presence in these high cellular stress environments, they do not upregulate autophagy. This is due to their basal level of autophagy being considerably elevated relative to normal cells. While the exact mechanism is unclear, there are theorized mechanisms such as oncogenic mutations causing an inhospitable environment leading to autophagy enhancement for overall survival [31]. The disruption and inhibition of this upregulated environment for the cancer cells has become a novel discussion in recent years as a potential target.

\subsection{Autophagy Pathways}

\subsubsection{Lysosomal Pathway}

The lysosomal pathway in autophagy has been the most widely studied. This process involves lysosomal digestion and recycling cytoplasmic components for cellular recycling. This differs from the contrasting ubiquitin-proteasome system (UPS), which is specifically mediated through the process of degradation of ubiquitinated proteins. Although a complex process, there appears to be crosstalk between the two pathways. While originally thought to be the "garbage disposal" of the cell, it is now known this process plays further roles such as intracellular transport, transduction signaling, and metabolism. The lysosomal pathway is an important potential therapeutic target because of its role in upregulation during cancer formation and growth [32]. Due to the increasingly inhospitable environment with rapidly dividing cells, resources become scarce. Therefore, upregulation of lysosomal degradation and an increase in lysosomal numbers for intracellular components becomes necessary for cellular survival. Lysosomes regulate intra- and extracellular $\mathrm{pH}$, helping ensure adequate homeostasis. Chloroquine and Hydroxychloroquine act through unclear mechanisms that do not allow lysosomes to fuse with autophagosomes while retaining their enzymatic function. Bafilomycin A1, through inhibition of the lysosomal V-ATPase, prevents acidification, causing autophagosomes that are engulfed by lysosomes of the vesicular organelles in its lumen, leading to cell death [16]. 


\subsubsection{Neddylation Pathway}

Neddylation has become an increasingly novel focus over the past few years as a target for anti-cancer therapy. This process has been shown to be overactive in a variety of human cancers, thus making it a desirable choice of therapeutic targeting [33]. It is similar to the ubiquitination pathway, with the exception of utilizing the NEDD-8 activating enzyme (NAE) as opposed to the E1 enzyme. The novel therapeutic Pevonedistat (MLN4924) has been shown to significantly increase cell apoptosis and autophagy via neddylation [34]. Neddylation may be an increased therapeutic benefit, as it also has other effects on the tumor microenvironment in comparison with other pathways [33].

\subsection{Clinical Trial Results}

\subsubsection{Chloroquine (CQ)}

As stated previously, the only FDA-approved autophagy agents are Chloroquine and Hydroxychloroquine [35]. Both function by inhibiting lysosomal acidification. In acidic environments, they become protonated and are then trapped inside the lysosome, causing increasing $\mathrm{pH}$. This increase in $\mathrm{pH}$ inhibits the ability of enzyme degradation, therefore creating a cytotoxic effect via the increased $\mathrm{pH}$, as the autophagy mechanism is inhibited. This blocks a survival mechanism that allows cancer cells to proliferate. The variability in effect of these therapies in different cancer lines can vary greatly, partly attributable to differing cancer types relying more on autophagy than others [36]. In trials for Chloroquine, monotherapy slightly outnumbered combination. This is in contrast with Hydroxychloroquine and Pevonedistat, where the majority of studies were conducted on combination therapies. Studies have demonstrated that combination therapy may seemingly work better than monotherapy [37]. The most studied cancer types in chloroquine trials were brain and breast, followed by lung and GI. These studies are outlined in Tables 1 and 2 and are discussed below.

Table 1. Characteristics of clinical trials of Chloroquine, Hydroxychloroquine, and Pevonedistat in clinical trials of cancer treatment by therapy type (monotherapy or combination with chemo), cancer type (liquid or solid), and trial phase.

\begin{tabular}{|c|c|c|c|}
\hline Therapy Type & Chloroquine & Hydroxychloroquine & Pevonedistat \\
\hline Monotherapy & 11 & 20 & 3 \\
\hline Combination & 7 & 66 & 34 \\
\hline Total & 18 & 86 & 37 \\
\hline \multicolumn{4}{|l|}{ Cancer Type } \\
\hline MDS & - & 1 & 13 \\
\hline Multiple Myeloma & 1 & 4 & 2 \\
\hline AML & - & 2 & 19 \\
\hline ALL & - & - & 1 \\
\hline CLL & - & 1 & \\
\hline Lymphoma & - & - & 4 \\
\hline \multicolumn{4}{|l|}{ Non-Hematological } \\
\hline Brain & 7 & 4 & 1 \\
\hline Brain Metastasis & 1 & - & - \\
\hline Endocrine & 1 & 1 & - \\
\hline Lung & 2 & 8 & 2 \\
\hline Breast & 3 & 9 & - \\
\hline GI & 2 & 22 & 1 \\
\hline Sarcoma/Bone Mets & 1 & 4 & - \\
\hline Melanoma & 1 & 8 & 1 \\
\hline Solid Neoplasms & 1 & 8 & 5 \\
\hline Renal & - & 1 & - \\
\hline Prostate & - & 9 & - \\
\hline Ovarian & - & 1 & - \\
\hline
\end{tabular}


Table 1. Cont.

\begin{tabular}{cccc}
\hline Therapy Type & Chloroquine & Hydroxychloroquine & Pevonedistat \\
\hline $\begin{array}{c}\text { Lymphangioleiomyomatosis } \\
\text { Mesothelioma } \\
\text { Phase }\end{array}$ & - & 1 & - \\
1 & & 19 \\
Phase I & - & 28 & 5 \\
Phase I/II & 6 & 25 & - \\
Phase II & 3 & 1 & 2 \\
Phase II/III & 5 & - & 1 \\
Phase III & - & 2 & 8 \\
Not Applicable & 3 & 16 & 8 \\
Published Results & 10 & & \\
\hline
\end{tabular}

Table 2. Clinical Trials for Chloroquine, Hydroxychloroquine, and Pevonedistat with results. Included are chemotherapy and/or immunotherapy included in trials.

\begin{tabular}{cccc}
\hline Trial & Indication & $\begin{array}{c}\text { Chemotherapy/ } \\
\text { Immunotherapy }\end{array}$ & Phase \\
\hline
\end{tabular}

\begin{tabular}{|c|c|c|c|c|}
\hline Chloroquine & & & & \\
\hline $\begin{array}{c}\text { NCT02333890 } \\
\text { [38] }\end{array}$ & Breast & $\mathrm{N} / \mathrm{A}$ & II & $\begin{array}{l}\text { Treatment with single-agent Chloroquine } 500 \mathrm{mg} \\
\text { daily in the preoperative setting was not } \\
\text { associated with any significant effects on breast } \\
\text { cancer cellular proliferation. It was, however, } \\
\text { associated with toxicity that may affect its } \\
\text { broader use in oncology. }\end{array}$ \\
\hline
\end{tabular}

$\begin{array}{ccc}\text { NCT01446016 } & \text { Breast } & \text { Taxane }\end{array}$

A combination of Chloroquine with taxane or taxane-like chemotherapy was efficacious in patients with locally advanced or metastatic breast cancer with prior anthracycline-based chemotherapy.

\begin{tabular}{|c|c|c|c|c|}
\hline $\begin{array}{c}\text { NCT02071537 } \\
{[40]}\end{array}$ & $\begin{array}{c}\text { Advanced Solid } \\
\text { Tumors }\end{array}$ & $\begin{array}{l}\text { Carboplatin } \\
\text { Gemcitabine }\end{array}$ & I & $\begin{array}{l}\text { Maximum tolerated dose of CQ was lower than } \\
\text { previously reported with concomitant use of } \\
\text { chemotherapeutic regimens. }\end{array}$ \\
\hline
\end{tabular}

$\begin{array}{ccc}\text { NCT01777477 } & \text { Pancreatic } & \text { Gemcitabine }\end{array}$

The addition of Chloroquine to gemcitabine was well tolerated and showed promising effects on the clinical response to the anti-cancer chemotherapy. Based on these initial results, the efficacy of the Gemcitabine-Chloroquine combination should be further assessed.

\begin{tabular}{|c|c|c|c|c|}
\hline $\begin{array}{c}\text { NCT01023477 } \\
\text { [42] }\end{array}$ & Breast & $\mathrm{N} / \mathrm{A}$ & $\mathrm{I} / \mathrm{II}$ & $\begin{array}{l}\text { Oral Chloroquine, as anti-autophagy therapy, } \\
\text { generates a measurable reduction in proliferation } \\
\text { of DCIS lesions and enhances immune cell } \\
\text { migration into the duct. }\end{array}$ \\
\hline $\begin{array}{c}\text { NCT02496741 } \\
{[43]}\end{array}$ & $\begin{array}{l}\text { Solid Tumors } \\
\text { (Glioma/ } \\
\text { Cholangiocarcinoma/ } \\
\text { Chondrosarcoma }\end{array}$ & $\mathrm{N} / \mathrm{A}$ & $1 / \mathrm{II}$ & $\begin{array}{l}\text { The combination regimen of metformin and } \\
\text { Chloroquine is well tolerated, but the } \\
\text { combination did not induce a clinical response in } \\
\text { this patient population. }\end{array}$ \\
\hline $\begin{array}{c}\text { NCT01727531 } \\
{[44]}\end{array}$ & Brain Metastasis & $\mathrm{N} / \mathrm{A}$ & II & $\begin{array}{l}\text { WBRT with concurrent, short-course CQ is well } \\
\text { tolerated in patients with brain metastases. The } \\
\text { high intracranial disease control rate warrants } \\
\text { additional study. }\end{array}$ \\
\hline
\end{tabular}


Table 2. Cont.

\begin{tabular}{|c|c|c|c|c|}
\hline Trial & Indication & $\begin{array}{l}\text { Chemotherapy/ } \\
\text { Immunotherapy }\end{array}$ & Phase & Results \\
\hline $\begin{array}{c}\text { NCT01438177 } \\
{[45]}\end{array}$ & Multiple Myeloma & $\begin{array}{c}\text { Velcade } \\
\text { Cyclophosphamide }\end{array}$ & II & $\begin{array}{l}\text { The addition of Chloroquine to bortezomib and } \\
\text { cyclophosphamide is effective and overcoming } \\
\text { probably some inhibitor resistance in a significant } \\
\text { fraction of heavily pre-treated patients, with an } \\
\text { acceptable toxicity profile. }\end{array}$ \\
\hline $\begin{array}{c}\text { NCT02378532 } \\
{[46]}\end{array}$ & Brain & Temozolomide & I & $\begin{array}{l}\text { A daily dose of } 200 \mathrm{mg} \text { CQ was established as the } \\
\text { MTD when combined with RT and concurrent } \\
\text { TMZ for newly diagnosed GBM. Favorable } \\
\text { tolerability supports further clinical trials. }\end{array}$ \\
\hline $\begin{array}{c}\text { NCT00224978 } \\
{[47]}\end{array}$ & Brain & Carmustine & III & $\begin{array}{l}\text { Chronic administration of Chloroquine greatly } \\
\text { enhanced the response of GB to antineoplastic } \\
\text { treatment. Because the toxicity of Chloroquine on } \\
\text { malignant cells is negligible, these favorable } \\
\text { results appear mediated by its strong } \\
\text { antimutagenic effect that precludes the } \\
\text { appearance of resistant clones during radio } \\
\text { and chemotherapy. }\end{array}$ \\
\hline
\end{tabular}

\section{Hydroxychloroquine}

\begin{tabular}{ccccc}
\hline $\begin{array}{c}\text { NCT01273805 } \\
{[48]}\end{array}$ & Pancreatic & N/A & II & $\begin{array}{c}\text { HCQ monotherapy achieved inconsistent } \\
\text { autophagy inhibition and demonstrated } \\
\text { negligible therapeutic efficacy. }\end{array}$ \\
\hline NCT00765765 & Breast & Ixabepilone & I/II & Terminated/No published data. \\
\hline NCT00786682 & Prostate & Docetaxel & II & Terminated/No published data. \\
\hline NCT01828476 & Prostate & $\begin{array}{c}\text { Abiraterone } \\
\text { ABT-263 }\end{array}$ & II & Terminated/No published data. \\
\hline NCT01006369 & Colorectal & $\begin{array}{c}\text { Capecitiabine } \\
\text { Oxalplatin } \\
\text { Bevacizumab }\end{array}$ & II & Completed/No published data. \\
\hline
\end{tabular}

Addition of Hydroxychloroquine is safe and tolerable, with a modest improvement in clinical responses compared with prior studies.

$\begin{array}{ccc}\text { NCT00728845 } & \text { Carboplatin } \\ \text { [49] } & \text { Lung } & \text { Paclitaxel } \\ & \text { Bevacizumab }\end{array}$

Autophagy inhibition may overcome

Bevacizumab

I/II chemotherapy resistance in advanced NSCLC, and further study in a more molecularly selected population such as KRAS-positive tumors is warranted.

\begin{tabular}{ccccc}
\hline $\begin{array}{c}\text { NCT02346340 } \\
\text { [50] }\end{array}$ & Colorectal & $\begin{array}{c}\text { Vorinostat } \\
\text { Regorafenib }\end{array}$ & II & $\begin{array}{c}\text { VOR/HCQ did not improve survival when } \\
\text { compared with RGF. }\end{array}$ \\
\hline $\begin{array}{c}\text { NCT03215264 } \\
\text { [51] }\end{array}$ & Colorectal & $\begin{array}{c}\text { Regorafenib } \\
\text { Entinostat }\end{array}$ & I & $\begin{array}{c}\text { The combination of regorafenib, HCQ, and } \\
\text { entinostat was poorly tolerated without evident } \\
\text { activity in metastatic colorectal cancer. }\end{array}$ \\
\hline $\begin{array}{c}\text { NCT01649947 } \\
\text { [52] }\end{array}$ & Lung & $\begin{array}{c}\text { Carboplatin } \\
\text { Paclitaxel } \\
\text { Bevacizumab }\end{array}$ & II & $\begin{array}{c}\text { Addition of HCQ has a similar toxicity profile } \\
\text { compared with chemotherapy alone. Response } \\
\text { rate to therapy in Kras-mutated and wild-type } \\
\text { tumors was similar; even the Kras-mutated } \\
\text { tumors usually demonstrate worse responses and } \\
\text { progression free survival to chemotherapy. }\end{array}$ \\
\hline $\begin{array}{c}\text { NCT02232243 } \\
\text { [53] }\end{array}$ & $\begin{array}{c}\text { Prostate/Lung/Head } \\
\text { and Neck }\end{array}$ & N/A & I & $\begin{array}{c}\text { Both dose levels of HCQ were well tolerated, and } \\
\text { Par-4 secretion but not induction of the } \\
\text { autophagy-inhibition of marker p62 correlated } \\
\text { with apoptosis induction in tumors. }\end{array}$ \\
\hline
\end{tabular}


Table 2. Cont.

\begin{tabular}{|c|c|c|c|c|}
\hline Trial & Indication & $\begin{array}{l}\text { Chemotherapy/ } \\
\text { Immunotherapy }\end{array}$ & Phase & Results \\
\hline $\begin{array}{c}\text { NCT00714181 } \\
{[54]}\end{array}$ & $\begin{array}{c}\text { Solid } \\
\text { Tumors/Melanoma }\end{array}$ & Temozolomide & I & $\begin{array}{l}\text { This study indicates that the combination of } \\
\text { high-dose HCQ and dose-intense TMZ is safe } \\
\text { and tolerable and is associated with autophagy } \\
\text { modulation in patients. }\end{array}$ \\
\hline $\begin{array}{l}\text { NCT01206530 } \\
{[55]}\end{array}$ & Colorectal & $\begin{array}{c}\text { FOLFOX } \\
\text { Bevacizumab }\end{array}$ & $\mathrm{I} / \mathrm{II}$ & $\begin{array}{l}\text { The combination of FOLFOX/bevacizumab with } \\
\text { HCQ is an active regimen in unselected patients } \\
\text { with colorectal cancer. A randomized phase II } \\
\text { trial of the combination is in development. }\end{array}$ \\
\hline $\begin{array}{c}\text { NCT01128296 } \\
{[56]}\end{array}$ & Pancreatic & Gemcitabine & $\mathrm{I} / \mathrm{II}$ & $\begin{array}{l}\text { Pre-operative autophagy inhibition with HCQ } \\
\text { plus gemcitabine is safe and well tolerated. } \\
\text { Surrogate biomarker responses (CA19-9) and } \\
\text { surgical oncologic outcomes were encouraging. } \\
\text { p53 status was not associated with } \\
\text { adverse outcomes. }\end{array}$ \\
\hline
\end{tabular}

\section{NCT01506973}

[57]

Pancreatic

Gemcitabine/nab-
Paclitaxel

I/II

The addition of HCQ to block autophagy did not improve the primary endpoint of overall survival at 12 months. However, improvement seen in the overall response rate with HCQ may indicate a role for HCQ in the locally advanced setting, where tumor response may permit resection.

HCQ with or without erlotinib was safe and well tolerated. The recommended phase 2 dose of HCQ was $1000 \mathrm{mg}$ when given in combination with erlotinib $150 \mathrm{mg}$.

Lung Erlotinib

[58]
Brain [59]

$\begin{array}{ccc}\begin{array}{c}\text { NCT00568880 } \\ \text { [60] }\end{array} & \text { Multiple Myeloma } & \text { Bortezomib } \\ & & \\ & & \\ \text { NCT01396200 } & \text { Multiple Myeloma } & \begin{array}{c}\text { Cyclophosphamide } \\ \text { Rapamycin }\end{array}\end{array}$

These data establish that autophagy inhibition is achievable with HCQ, but dose-limiting toxicity prevented escalation to higher doses of HCQ.

Patients are awaiting the development of lower-toxicity compounds that can achieve more consistent inhibition of autophagy than HCQ.

Combined targeting of proteasomal and autophagic protein degradation using bortezomib and Hydroxychloroquine is therefore feasible and a potentially useful strategy for improving outcomes in myeloma therapy.

The addition of mTOR and autophagy inhibition to a backbone of cy/dex yields a tolerable regimen with durable responses in heavily pretreated patients. A randomized phase 2 study is needed to determine the synergistic properties of dual mTOR and autophagy inhibition vs. chemotherapy alone.

NCT01550367
[62]

\section{NCT01687179} [63]
Lymphangioleiomyomatosis Sirolimus
N/A (IL-2)

I/II
IL-2 plus HCQ was well tolerated and clinically active, with encouraging PFS of 17 months at the $600 \mathrm{mg}$ HCQ dose.

The combination of Sirolimus and Gydroxychloroquine is well tolerated, with no dose-limiting adverse events observed at $200 \mathrm{mg}$ twice a day. Potential effects on lung function should be explored in larger trials. 
Table 2. Cont.

\begin{tabular}{|c|c|c|c|c|}
\hline Trial & Indication & $\begin{array}{l}\text { Chemotherapy/ } \\
\text { Immunotherapy }\end{array}$ & Phase & Results \\
\hline $\begin{array}{l}\text { NCT01510119 } \\
{[64]}\end{array}$ & $\mathrm{RCC}$ & Everolimus & $\mathrm{I} / \mathrm{II}$ & $\begin{array}{c}\text { Combined Hydroxychloroquine } 600 \mathrm{mg} \text { twice } \\
\text { daily with } 10 \text { mg daily everolimus was tolerable. } \\
\text { The primary endpoint of }>40 \% \text { 6-month PFS rate } \\
\text { was met. Hydroxychloroquine is a tolerable } \\
\text { autophagy inhibitor for future RCC } \\
\text { or other trials. }\end{array}$ \\
\hline NCT03344172 & Pancreatic & $\begin{array}{l}\text { Gemcitabine, } \\
\text { Abraxane, } \\
\text { Avelumab }\end{array}$ & II & Terminated/No published results. \\
\hline $\begin{array}{l}\text { NCT01978184 } \\
{[65]}\end{array}$ & Pancreatic & $\begin{array}{l}\text { Gemcitabine, } \\
\text { Abraxane }\end{array}$ & II & $\begin{array}{l}\text { The addition of Hydroxychloroquine to } \\
\text { preoperative gemcitabine and nab-paclitaxel } \\
\text { chemotherapy in patients with respectable } \\
\text { pancreatic adenocarcinoma resulted in greater } \\
\text { pathologic tumor response, improved serum } \\
\text { biomarker response, and evidence of autophagy } \\
\text { inhibition and immune activity }\end{array}$ \\
\hline NCT02013778 & $\mathrm{HCC}$ & N/A (TACE) & I/II & Terminated/No published data. \\
\hline \multicolumn{5}{|l|}{ Pevonedistat } \\
\hline $\begin{array}{l}\text { NCT01862328 } \\
{[66]}\end{array}$ & Solid Tumors & $\begin{array}{l}\text { Paclitaxel } \\
\text { Gemcitabine } \\
\text { Docetaxel } \\
\text { Carboplatin }\end{array}$ & I & $\begin{array}{l}\text { Pevonedistat with docetaxel or with carboplatin } \\
\text { plus paclitaxel was tolerable without cumulative } \\
\text { toxicity. Sustained clinical responses were } \\
\text { observed in pretreated patients receiving } \\
\text { Ppevonedistat with carboplatin and paclitaxel. }\end{array}$ \\
\hline $\begin{array}{l}\text { NCT03057366 } \\
\text { [67] }\end{array}$ & Solid Tumors & $\begin{array}{l}\text { Docetaxel } \\
\text { Carboplatin } \\
\text { Paclitaxel }\end{array}$ & I & $\begin{array}{l}\text { Pevonedistat in combination with docetaxel or } \\
\text { carboplatin plus paclitaxel was generally well } \\
\text { tolerated. }\end{array}$ \\
\hline $\begin{array}{l}\text { NCT01814826 } \\
{[68]}\end{array}$ & AML & Azacitidine & I & $\begin{array}{l}\text { Pevonedistat/azacitidine combo did not alter } \\
\text { toxicity profile of azacytidine. Intent to treat ORR } \\
\text { was } 50 \% \text {. }\end{array}$ \\
\hline NCT00722488 & $\begin{array}{l}\text { Multiple Myeloma } \\
\text { Lymphoma }\end{array}$ & $\mathrm{N} / \mathrm{A}$ & I & Unable to obtain abstract. \\
\hline NCT03709576 & AML & Azacitidine & II & Terminated/No published results. \\
\hline $\begin{array}{l}\text { NCT01011530 } \\
{[69]}\end{array}$ & Melanoma & $\mathrm{N} / \mathrm{A}$ & I & $\begin{array}{l}\text { MLN4924 is generally well tolerated at the doses } \\
\text { tested on schedule A, with antitumor activity. }\end{array}$ \\
\hline $\begin{array}{l}\text { NCT02610777 } \\
\text { [70] }\end{array}$ & MDS & Azacizidine & II & $\begin{array}{l}\text { The OS, EFS, and ORR benefits were particularly } \\
\text { promising among patients with higher-risk MDS, } \\
\text { as was the OS benefit in LB-AML. The addition of } \\
\text { Pevonedistat to azacitidine resulted in a } \\
\text { comparable safety profile to azacitidine alone, no } \\
\text { increased myelosuppression, and azacitidine } \\
\text { dose intensity was maintained. }\end{array}$ \\
\hline $\begin{array}{l}\text { NCT00911066 } \\
{[71]}\end{array}$ & $\begin{array}{l}\text { AML } \\
\text { MDS }\end{array}$ & $\mathrm{N} / \mathrm{A}$ & 1 & $\begin{array}{c}\text { Administration of the first-in-class agent, } \\
\text { Ppevonedistat, was feasible in patients with MDS } \\
\text { and AML, and modest clinical activity } \\
\text { was observed. }\end{array}$ \\
\hline
\end{tabular}

Brain

In a phase I trial with temozolomide, there was a favorable toxicity profile [46]. A phase II trial also demonstrated excellent tolerability in patients receiving whole brain radiation therapy (WBRT) [44]. The only phase III trial showed an enhanced response 
in glioblastoma multiforme. Chloroquine coadministration with Carmustine enhanced activity in resistant clones during radio and chemotherapy [47].

Breast

Chloroquine was associated with positive results in two out of three trials. A phase I/II study demonstrated a measurable reduction in proliferation in DCIS. There was also immune cell migration, specifically with macrophages, into the ducts that was observed [42]. One study with single agent used preoperatively failed to demonstrate any clinically significant effects on proliferation [38]. They concluded that the toxicity was negligible compared with placebo but that the effects were also negligible.

In a phase II randomized control trial (RCT) trial by Arnaout, KI67 index was demonstrated to not be lowered with use of Chloroquine supplementation as a mono therapy compared with placebo. It was speculated that autophagy inhibitors may be more beneficial in combination therapy and more synergistically beneficial when tumor cells are placed under stress [38]. This highlights the overall generality seen, in which combination therapy with antineoplastic agents in coadministration with Chloroquine sees better response, specifically with proliferation, in the clinical trials presented.

\subsubsection{Hydroxychloroquine (HCQ)}

Miscellaneous Tumors

Rosenfeld et al. provided data showing a dose-limiting toxicity with HCQ use with temozolomide. No reduction in proliferation was demonstrated [59]. High-dose HCQ and dose-intense temozolomide were found to be safe and tolerable and were associated with autophagy modulation in patients with melanoma [54].

\section{Lung}

Modest improvements in clinical responses have been shown in HCQ with carboplatin/paclitaxel/bevacizumab treatment compared with previous studies [49]. Further phase II trials have shown promising effects in Kras-mutated lung cancers, opening up the possibilities of further therapeutic options in chemoresistant cancers [52]. The only other lung cancer trial, phase I, showed a safe toxicity and tolerability profile when given with erlotinib [58].

\section{Gastrointestinal}

In pancreatic trials, monotherapy demonstrated inconsistent autophagy inhibitory effects along with clinically insignificant therapeutic efficacy [48]. Other monotherapy trials demonstrated safe toxicity profiles but were not clinically significant and showed no difference in outcomes with p53 status of individual patients. These trials contrasted with combination therapy including gemcitabine and nab-paclitaxel, in which greater pathologic and biomarker response increased, along with autophagy inhabitation and immune activity [56].

Colorectal cancer showed fewer promising results, with some findings from phase I and I/II. HCQ, regorafenib and etinostat were poorly tolerated [50]. In another trial comparing vorinostat and HCQ combination with Regorafenib alone, there was no survival improvement [51]. A phase I/II with folfox/bevacizumab with HCQ was well tolerated, although the second phase of study has not compiled results at this time [55].

\section{Renal Cell Carcinoma}

HCQ with everolimus showed tolerability in combination phase I/II trial. The primary endpoint of a 6-month PFS of 40\% was met, showing encouraging results [62]. Another phase I trial with IL-2 (no chemotherapy) also demonstrated a PFS of 17 months with a $600 \mathrm{mg}$ dose monotherapy [64]. 


\section{Multiple Myeloma}

Both the multiple myeloma trials concerning HCQ were phase I combination trials, one with bortezomib and cyclophosphamide/rapamycin. The addition of mammalian target of rampiclin (mTOR) and autophagy inhibition with cyclophosphamide yields a regimen with low toxicity that is tolerable in heavily pretreated patients. Both trials stated that phase II trials are needed for further elucidation of synergistic effects with other myeloma regimens $[60,61]$.

\subsection{Pevonedistat (MLN4924)}

A more recent drug that has sparked clinical interest is Pevonedistat, with a more novel pathway of NEDD-9 inhibition leading to autophagy activation. Pevonedistat differs in terms of CQ/HCQ in that it is a pro-apoptotic and autophagy inducer, rather than inhibitor. Many of the clinical trials conducted were for hematological malignancies. Many of these trails were combination therapy vs. monotherapy. There were two phase II trials out of 8 total trials, with one being terminated and one showing promising results. Trial NCT02610777, involving Pevonedistat plus azacytidine vs. azacytidine alone, had promising OS, EFS, ORR, and OS, with similar patient side effect profiles [70]. All other phase I trials demonstrated generally well-tolerated side effects with Pevonedistat use [66-69,71]. Two trials had unavailable results—one due to termination and one with an inaccessible abstract.

\subsection{Autophagy Inhibitors as Monotherapy vs. Combination}

In cancer cells, multiple studies have demonstrated that autophagy suppression along with creating a cytotoxic environment with chemotherapy can disrupt cancer homeostasis far greater than either agent alone. Combination chemotherapy has been a cornerstone of cancer therapy, and in this regard the data seem to be applicable to autophagy as well. As seen in Table 1, the clinical trials associated with these show a higher number in combination as compared with monotherapy alone.

Theories have been proposed as to why combination may have seemingly more clinically efficacious results - the main theory being oxidation with use from antineoplastic therapy creates intracellular stress, ROS, and invokes starvation creating cytotoxic environments. The upregulated autophagocytic process normally present at a basal level in cancer cells is unable to function properly when antiautophagocytic agents are present [72] Another is autophagy inhibitors and pro-apoptotic agents' ability to enhance cancer cell radiosensitivity [72,73]. While not widely studied, autophagy inhibitors and activators (mTOR inhibitors) have been used with synergistic results [74]. This could lead to novel pathways in mTOR-resistant cancers.

\subsection{Adverse Effects Associated with Autophagy Agents}

Due to the recency of which these agents have been utilized in a clinical setting, we cannot fully evaluate the potential long-term side effects. Although these may be used as a tumor suppressor and may aid in malignant therapeutics, considerations must be taken into effect on potentiating other diseases, such neurodegenerative diseases in which autophagy can be protective [75]. A limitation of this review is that the trials are mainly phase I and/or II and that side effects may be present that were not discovered at this stage. However, note that most trials did not indicate that such toxicities were associated with results, and they did not demonstrate harmful effects that would prevent progression to a phase II or III trial. Side effects associated with use were mainly GI related, with nausea, emesis, and diarrhea.

\subsection{Tumor Response and Ki67}

A randomized control trial that included 70 breast cancer patients was designed to evaluate effects on tumor of daily CQ supplementation at a dose of $500 \mathrm{mg}$ daily. It was found that there was no significant difference in tumor Ki-67 index between both CQ and placebo groups [38]. Similarly, a phase II randomized clinical trial found that 
HCQ combination with gemcitabine and nab-paclitaxel did not improve 12-month overall survival among patients with metastatic pancreatic cancer. However, in the same study, overall response rate of advanced tumors showed improvement with continuous addition of $600 \mathrm{mg}$ HCQ twice daily that may permit resection of tumor. A similar study analyzed the effect of combining HCQ with pre-operative gemcitabine and nab-paclitaxel chemotherapy in patients with pancreatic adenocarcinoma and found significant results. This study employed 64 patients and found administration of HCQ correlated with an increase in the means of patients with the tumor. This immune system alteration in the resected tumor correlated with improved overall survival in recurrence-free survival [56]. It is not surprising given that Pevonedistat, being a newer drug, has clinical trials that are less numerous, and therefore limited results.

\subsection{Strengths and Weakness of Autophagy Inhibitors in Cancer}

While Chloroquine does impact intracellular $\mathrm{pH}$ in acidic parts of the cell, it is limited in its ability to permeate the cellular membrane in the presence of an acidic environment [76,77]. This is highly disadvantageous since the tumor microenvironment is more acidic than at homeostatic levels. This can be attributed to the Warburg effect in which cancer cells use glycolysis in lieu of anaerobic respiration [77]. As discussed previously, effects of autophagy inhibitors can inadvertently promote antitumor mechanisms. This mechanism occurs through pathways such as the promotion of T-regs that can damper down the innate immune system alarm for tumor escape and upregulation in transcription factors in conjunction with other anti-neoplastic therapies due to cellular stress. For example, alkylating agents activate ataxia telangiectasis-mutated kinase (ATM), which increases cancer cells upregulation of autophagy to help in survival [78]. In turn, this increases a protective effect in regular glycolysis, resulting in increasing lactate creating the acidic environment that may be detrimental to Chloroquine/Hydroxychloroquine effects. The effect of acidification must be taken into account as well with other therapeutic options.

Depending on cellular conditions, autophagy has been shown to increase and decrease immune response in certain immunotherapies [79]. This can be seen by immunological response of CQ-immune cancer antigens. In immunocompetent mice, CQ decreased acidification into lysosomes, which in turn has been shown to hinder CD4 positive T cells. Conversely, in the T cell deficient, most Chloroquine has been demonstrated to increase NK cells and upregulate TNF, leading to more antitumor response [78]. One potential benefit of autophagy inhibition is the evidence demonstrating the lower risk of metastasis. This mechanism is achieved through the disruption of epithelial to mesenchymal transfer. Of note, this benefit is limited to malignant cells that are less differentiated and possess more stem cell-like features. These limitations have also been seen with mTOR inhibitors' ability to slow progression but limited cell death [80].

\section{Conclusions and Future Directions for Autophagy Agents in Cancer Therapy}

Both Chloroquine and Hydroxychloroquine demonstrate inhibitory effects on autophagy, making them potential targets for future cancer therapies. In this paper we have provided an overview of the characteristics of the clinical trials with Chloroquine, Hydroxychloroquine, and novel drug Pevonedistat. Interestingly, to our knowledge, there are no current trials combining agents that are pro-apoptotic and autophagy inhibitors. Given that Chloroquine and Hydroxychloroquine are autophagy inhibitors, while Pevonedistat is a pro-apoptotic agent, this has potential to lead to more interesting results used in combination to approach multiple sites of therapeutic significance.

There are limitations to use of autophagy inhibitors, and these can also be seen with mTOR inhibitors, as discussed previously. Further understanding of the process with future clinical trials will likely yield information and results that guide drug discovery. While Chloroquine and Hydroxychloroquine are the only FDA-approved autophagy inhibitors, there are promising results in terms of toxicity in early phase studies, but further clinical trials are needed to see clinical benefit with other therapies. 


\begin{abstract}
Author Contributions: S.M. contributed to research, data collection, review drafting, and editing of this manuscript; P.T.S. contributed to research, data collection, review drafting, and editing of this manuscript; G.F.A. contributed to research and data collection; N.N. contributed to research and data collection; S.A.A.-Z. contributed to research and data collection; N.A.K. contributed to development of the concept and rationale, research, data collection, review drafting, and editing of this manuscript. All authors have read and agreed to the published version of the manuscript.
\end{abstract}

Funding: This research received no external funding.

Conflicts of Interest: The authors declare no conflict of interest.

\title{
References
}

1. Deter, R.L.; De Duve, C. Influence of glucagon, an inducer of cellular autophagy, on some physical properties of rat liver lysosomes. J. Cell Biol. 1967, 33, 437-449. [CrossRef]

2. Focusing on autophagy. Nat. Cell Biol. 2010, 12, 813. [CrossRef] [PubMed]

3. Deretic, V. Autophagosome and Phagosome. In Autophagosome and Phagosome; Humana Press: Totowa, NJ, USA, 2008; pp. 1-10.

4. Dunn, W.A. Autophagy and Related Mechanisms of Lysosome-Mediated Protein Degradation; Elsevier Ltd.: London, UK, 1994.

5. Stolz, A.; Ernst, A.; Dikic, I. Cargo recognition and trafficking in selective autophagy. Nat. Cell Biol. 2014, 16, 495-501. [CrossRef] [PubMed]

6. Arias, E.; Cuervo, A.M. Chaperone-mediated autophagy in protein quality control. Curr. Opin. Cell Biol. 2011, 23, 184-189. [CrossRef] [PubMed]

7. Pengo, N.; Scolari, M.; Oliva, L.; Milan, E.; Mainoldi, F.; Raimondi, A.; Fagioli, C.; Merlini, A.; Mariani, E.; Pasqualetto, E.; et al. Plasma cells require autophagy for sustainable immunoglobulin production. Nat. Immunol. 2013, 14, 298-305. [CrossRef] [PubMed]

8. Sui, X.; Chen, R.; Wang, Z.; Huang, Z.; Kong, N.; Zhang, M.; Han, W.; Lou, F.; Yang, J.; Zhang, Q.; et al. Autophagy and chemotherapy resistance: A promising therapeutic target for cancer treatment. Cell Death Dis. 2013, 4, e838. [CrossRef]

9. Hu, C.; Solomon, V.R.; Ulibarri, G.; Lee, H. The efficacy and selectivity of tumor cell killing by akt inhibitors are substantially increased by chloroquine. Bioorganic Med. Chem. 2008, 16, 7888-7893. [CrossRef]

10. Kumar, D.; Gupta, D.; Shankar, S.; Srivastava, R.K. Biomolecular characterization of exosomes released from cancer stem cells: Possible implications for biomarker and treatment of cancer. Oncotarget 2015, 6, 3280-3291. [CrossRef]

11. Raposo, G.; Stoorvogel, W. Extracellular vesicles: Exosomes, microvesicles, and friends. J. Cell Biol. 2013, 200, 373-383. [CrossRef]

12. Sharifi, M.N.; Mowers, E.E.; Drake, L.E.; Macleod, K.F. Measuring Autophagy in Stressed Cells; Stress Responses: New York, NY, USA; Springer: New York, NY, USA, 2015; pp. 129-150.

13. Mijaljica, D.; Prescott, M.; Devenish, R.J. Microautophagy in mammalian cells: Revisiting a 40-year-old conundrum. Autophagy 2011, 7, 673-682. [CrossRef]

14. Geser, A.; Brubaker, G.; Draper, C.C. Effect of a malaria suppression program on the incidence of african burkitt's lymphoma. Am. J. Epidemiol. 1989, 129, 740-752. [CrossRef] [PubMed]

15. Ganguli, A.; Choudhury, D.; Datta, S.; Bhattacharya, S.; Chakrabarti, G. Inhibition of autophagy by chloroquine potentiates synergistically anti-cancer property of artemisinin by promoting ROS dependent apoptosis. Biochimie 2014, 107, 338-349. [CrossRef] [PubMed]

16. Mauthe, M.; Orhon, I.; Rocchi, C.; Zhou, X.; Luhr, M.; Hijlkema, K.-J.; Coppes, R.P.; Engedal, N.; Mari, M.; Reggiori, F. Chloroquine inhibits autophagic flux by decreasing autophagosome-lysosome fusion. Autophagy 2018, 14, 1435-1455. [CrossRef] [PubMed]

17. Münz, C. Autophagy Beyond Intracellular MHC Class II Antigen Presentation; Elsevier: Amsterdam, The Netherlands, 2016.

18. Shibutani, S.T.; Saitoh, T.; Nowag, H.; Münz, C.; Yoshimori, T. Autophagy and autophagy-related proteins in the immune system. Nat. Immunol. 2015, 16, 1014-1024. [CrossRef]

19. Richetta, C.; Faure, M. Autophagy in antiviral innate immunity. Cell. Microbiol. 2012, 15, 368-376. [CrossRef]

20. Viry, E.; Noman, M.Z.; Arakelian, T.; Lequeux, A.; Chouaib, S.; Berchem, G.; Moussay, E.; Paggetti, J.; Janji, B. Hijacker of the antitumor immune response: Autophagy is showing its worst facet. Front. Oncol. 2016, 6, 246. [CrossRef]

21. Paquette, M.; El-Houjeiri, L.; Pause, A. mTOR pathways in cancer and autophagy. Cancers 2018, 10, 18. [CrossRef]

22. Semenza, G.L. Hypoxia-inducible factors: Mediators of cancer progression and targets for cancer therapy. Trends Pharmacol. Sci. 2012, 33, 207-214. [CrossRef]

23. Liang, X.; Tang, J.; Liang, Y.; Jin, R.; Cai, X. Suppression of autophagy by chloroquine sensitizes 5-fluorouracil-mediated cell death in gallbladder carcinoma cells. Cell Biosci. 2014, 4, 10. [CrossRef]

24. Simons, M.; Raposo, G. Exosomes-vesicular carriers for intercellular communication. Curr. Opin. Cell Biol. 2009, $21,575-581$. [CrossRef]

25. Fader, C.; Colombo, M.I. Multivesicular bodies and autophagy in erythrocyte maturation. Autophagy 2006, 2, 122-125. [CrossRef] [PubMed]

26. Jiang, Y.; Ji, F.; Liu, Y.; He, M.; Zhang, Z.; Yang, J.; Wang, N.; Zhong, C.; Jin, Q.; Ye, X.; et al. Cisplatin-induced autophagy protects breast cancer cells from apoptosis by regulating yes-associated protein. Oncol. Rep. 2017, 38, 3668-3676. [CrossRef] 
27. Komatsu, M.; Waguri, S.; Chiba, T.; Murata, S.; Iwata, J.-I.; Tanida, I.; Ueno, T.; Koike, M.; Uchiyama, Y.; Kominami, E.; et al. Loss of autophagy in the central nervous system causes neurodegeneration in mice. Nature 2006, 441, 880-884. [CrossRef] [PubMed]

28. Jin, S.; White, E. Role of autophagy in cancer: Management of metabolic stress. Autophagy 2007, 3, 28-31. [CrossRef] [PubMed]

29. Gilad, Y.; Eliaz, Y.; Yu, Y.; Han, S.J.; O'Malley, B.W.; Lonard, D.M. Drug-induced PD-L1 expression and cell stress response in breast cancer cells can be balanced by drug combination. Sci. Rep. 2019, 9, 15099. [CrossRef] [PubMed]

30. Thorburn, A.; Thamm, D.; Gustafson, D.L. Autophagy and cancer therapy. Mol. Pharmacol. 2014, 85, 830-838. [CrossRef]

31. Sharif, T.; Martell, E.; Dai, C.; Kennedy, B.E.; Murphy, P.; Clements, D.R.; Kim, Y.; Lee, P.W.K.; Gujar, S.A. Autophagic homeostasis is required for the pluripotency of cancer stem cells. Autophagy 2017, 13, 264-284. [CrossRef]

32. Lim, S.M.; Hanif, E.A.M.; Chin, S.-F. Is targeting autophagy mechanism in cancer a good approach? the possible double-edge sword effect. Cell Biosci. 2021, 11, 56. [CrossRef]

33. Zhou, L.; Jiang, Y.; Luo, Q.; Li, L.; Jia, L. Neddylation: A novel modulator of the tumor microenvironment. Molecular cancer Mol. Cancer 2019, 18, 77. [CrossRef]

34. Soucy, T.A.; Dick, L.R.; Smith, P.G.; Milhollen, M.A.; Brownell, J.E. The NEDD8 conjugation pathway and its relevance in cancer biology and therapy. Genes Cancer 2010, 1, 708-716. [CrossRef]

35. Manic, G.; Obrist, F.; Kroemer, G.; Vitale, I.; Galluzzi, L. Chloroquine and hydroxychloroquine for cancer therapy. Mol. Cell. Oncol. 2014, 1, e29911. [CrossRef] [PubMed]

36. Santana-Codina, N.; Mancias, J.D.; Kimmelman, A.C. The role of autophagy in cancer. Annu. Rev. Cancer Biol. 2017, 1, 19-39. [CrossRef] [PubMed]

37. Chude, C.I.; Amaravadi, R.K. Targeting autophagy in cancer: Update on clinical trials and novel inhibitors. Int. J. Mol. Sci. 2017, 18, 1279. [CrossRef] [PubMed]

38. Arnaout, A.; Robertson, S.J.; Pond, G.R.; Lee, H.; Jeong, A.; Ianni, L.; Kroeger, L.; Hilton, J.; Coupland, S.; Gottlieb, C.; et al A randomized, double-blind, window of opportunity trial evaluating the effects of chloroquine in breast cancer patients. Breast Cancer Res. Treat. 2019, 178, 327-335. [CrossRef]

39. Anand, K.; Niravath, P.; Patel, T.; Ensor, J.; Rodriguez, A.; Boone, T.; Wong, S.T.; Chang, J.C. A phase II study of the efficacy and safety of chloroquine in combination with taxanes in the treatment of patients with advanced or metastatic anthracycline-refractory breast cancer. Clin. Breast Cancer 2021, 21, 199-204. [CrossRef]

40. Abdel Karim, N.F.; Ahmad, I.; Gaber, O.; Eldessouki, I.; Olowokure, O.O.; Farooq, M.; Morris, J.C. Phase I trial of chloroquine (CQ) / hydroxychloroquine (HCQ) in combination with carboplatin-gemcitabine (CG) in patients with advanced solid tumors. J. Clin. Oncol. 2019, 37 (Suppl. 15), 3027. [CrossRef]

41. Samaras, P.; Tusup, M.; Nguyen-Kim, T.D.L.; Seifert, B.; Bachmann, H.; Von Moos, R.; Knuth, A.; Pascolo, S. Phase I study of a chloroquine-gemcitabine combination in patients with metastatic or unresectable pancreatic cancer. Cancer Chemother. Pharmacol. 2017, 80, 1005-1012. [CrossRef]

42. Espina, V.A.; Liotta, L.; Rassulova, S.; Gallimore, H.; Grant-Wisdom, T.; Menezes, G.; Nayer, H.; Edmiston, K. Abstract CT140: PINC trial: Preventing invasive breast neoplasia with chloroquine. Clinical Trials 2017, 77, CT140. [CrossRef]

43. Khurshed, M.; Molenaar, R.; van Linde, M.; Mathôt, R.; Struys, E.; van Wezel, T.; van Noorden, C.; Klümpen, H.-J.; Bovée, J.; Wilmink, J. A phase ib clinical trial of metformin and chloroquine in patients with idh1-mutated solid tumors. Cancers 2021, 13, 2474. [CrossRef]

44. Eldredge, H.B.; DeNittis, A.; DuHadaway, J.B.; Chernick, M.; Metz, R.; Prendergast, G.C. Concurrent whole brain radiotherapy and short-course chloroquine in patients with brain metastases: A pilot trial. J. Radiat. Oncol. 2013, 2, 315-321. [CrossRef]

45. Montanari, F.; Lu, M.; Marcus, S.; Saran, A.; Malankar, A.; Mazumder, A. A phase II trial of chloroquine in combination with bortezomib and cyclophosphamide in patients with relapsed and refractory multiple myeloma. Blood 2014, 124, 5775. [CrossRef]

46. Compter, I.; Eekers, D.; Hoeben, A.; Rouschop, K.; Reymen, B.; Ackermans, L.; Beckervordersantforth, J.; Bauer, N.; Anten, M.; Wesseling, P.; et al. CHLOROBRAIN phase IB trial: The addition of chloroquine, an autophagy inhibitor, to concurrent radiation and temozolomide for newly diagnosed glioblastoma. Ann. Oncol. 2019, 30, v154. [CrossRef]

47. Briceño, E.; Reyes, S.; Sotelo, J. Therapy of glioblastoma multiforme improved by the antimutagenic chloroquine. Neurosurg. Focus 2003, 14, 1-6. [CrossRef]

48. Wolpin, B.M.; Rubinson, D.A.; Wang, X.; Chan, J.A.; Cleary, J.M.; Enzinger, P.C.; Fuchs, C.S.; McCleary, N.J.; Meyerhardt, J.A.; Ng, K.; et al. Phase II and pharmacodynamic study of autophagy inhibition using hydroxychloroquine in patients with metastatic pancreatic adenocarcinoma. Oncologist 2014, 19, 637-638. [CrossRef] [PubMed]

49. Malhotra, J.; Jabbour, S.; Orlick, M.; Riedlinger, G.; Guo, Y.; White, E.; Aisner, J. Phase ib/II study of hydroxychloroquine in combination with chemotherapy in patients with metastatic non-small cell lung cancer (NSCLC). Cancer Treat. Res. Commun. 2019, 21, 100158. [CrossRef] [PubMed]

50. Arora, S.P.; Tenner, L.L.; Sarantopoulos, J.; Morris, J.L.; Longoria, L.; Liu, Q.; Michalek, J.; Mahalingam, D. Modulation of autophagy: A phase II study of vorinostat (VOR) plus hydroxychloroquine (HCQ) vs. regorafenib (RGF) in chemo-refractory metastatic colorectal cancer (mCRC). J. Clin. Oncol. 2019, 37, 3551. [CrossRef]

51. Brown, T.J.; Karasic, T.B.; Schneider, C.J.; Teitelbaum, U.R.; Reiss, K.A.; Mitchell, T.C.; Massa, R.C.; O’Hara, M.H.; DiCicco, L.; Garcia-Marcano, L.; et al. Phase I trial of regorafenib, hydroxychloroquine, and entinostat in metastatic colorectal cancer. J. Clin. Oncol. 2021, 39, e15580. [CrossRef] 
52. Malhotra, J.; Jabbour, S.; Orlick, M.; Riedlinger, G.; Joshi, S.; Guo, J.Y.; White, E.; Aisner, J. Modulation of autophagy with hydroxychloroquine in patients with advanced non-small cell lung cancer (NSCLC): A phase ib study. J. Clin. Oncol. 2018, 36, e21138. [CrossRef]

53. Wang, P.; Burikhanov, R.; Jayswal, R.; Weiss, H.L.; Arnold, S.M.; Villano, J.L.; Rangnekar, V.M. Neoadjuvant administration of hydroxychloroquine in a phase 1 clinical trial induced plasma par-4 levels and apoptosis in diverse tumors. Genes Cancer 2018, 9 , 190-197. [CrossRef]

54. Rangwala, R.; Leone, R.; Chang, Y.C.; Fecher, L.A.; Schuchter, L.M.; Kramer, A.; Tan, K.-S.; Heitjan, D.F.; Rodgers, G.; Gallagher, M.; et al. Phase I trial of hydroxychloroquine with dose-intense temozolomide in patients with advanced solid tumors and melanoma. Autophagy 2014, 10, 1369-1379. [CrossRef]

55. Loaiza-Bonilla, A.; O’Hara, M.H.; Redlinger, M.; Damjanov, N.; Teitelbaum, U.R.; Vasilevskaya, I.; Rosen, M.A.; Heitjan, D.F.; Amaravadi, R.K.; O'Dwyer, P.J. Phase II trial of autophagy inhibition using hydroxychloroquine (HCQ) with FOLFOX/bevacizumab in the first-line treatment of advanced colorectal cancer. J. Clin. Oncol. 2015, 33, 3614. [CrossRef]

56. Boone, B.A.; Bahary, N.; Zureikat, A.; Moser, A.J.; Normolle, D.; Wu, W.; Singhi, A.D.; Bao, P.; Bartlett, D.; Liotta, L.; et al. Safety and Biologic Response of Pre-Operative Autophagy Inhibition with Gemcitabine in Patients with Pancreatic Adenocarcinoma. Ann. Surg. Oncol. 2015, 22, 4402-4410. [CrossRef] [PubMed]

57. Karasic, T.B.; O’Hara, M.H.; Loaiza-Bonilla, A.; Reiss, K.A.; Teitelbaum, U.R.; Borazanci, E.; De Jesus-Acosta, A.; Redlinger, C.; Burrell, J.A.; Laheru, D.A.; et al. Effect of gemcitabine and nab-paclitaxel with or without hydroxychloroquine on patients with advanced pancreatic cancer: A phase 2 randomized clinical trial. JAMA Oncol. 2019, 5, 993-998. [CrossRef] [PubMed]

58. Goldberg, S.B.; Supko, J.G.; Neal, J.W.; Muzikansky, A.; Digumarthy, S.; Fidias, P.; Temel, J.S.; Heist, R.S.; Shaw, A.T.; McCarthy, P.O.; et al. A phase I study of erlotinib and hydroxychloroquine in advanced Non-Small-cell lung cancer. J. Thorac. Oncol. 2012, 7, 1602-1608. [CrossRef]

59. Rosenfeld, M.R.; Ye, X.; Supko, J.G.; Desideri, S.; Grossman, S.A.; Brem, S.; Mikkelson, T.; Wang, D.; Chang, Y.C.; Hu, J.; et al. A phase I/II trial of hydroxychloroquine in conjunction with radiation therapy and concurrent and adjuvant temozolomide in patients with newly diagnosed glioblastoma multiforme. Autophagy 2014, 10, 1359-1368. [CrossRef]

60. Vogl, D.T.; Stadtmauer, E.A.; Bradner, J.; Davis, L.; Paul, T.M.; Scott, E.C.; Nichols, C.W.; Porter, D.L.; Carroll, M.; Kaplan, J.; et al. Combined autophagy and proteasome inhibition for multiple myeloma: Final results of a phase 1 trial of hydroxychloroquine and standard dose bortezomib for patients with relapsed or refractory myeloma. Blood 2011, 118, 1869. [CrossRef]

61. Scott, E.C.; Vogl, D.T.; Reasor-Heard, S.; Floyd, K.; Medvedova, E.; Spurgeon, S.E.; Gordon, M.; Kratz, A.; Siegel, M.B.; Loriaux, M.; et al. A phase I study of hydroxychloroquine with infusional cyclophosphamide, pulse dexamethasone and rapamycin in patients with relapsed or refractory multiple myeloma. Blood 2014, 124, 3449. [CrossRef]

62. Appleman, L.J.; Normolle, D.P.; Logan, T.F.; Monk, P.; Olencki, T.; McDermott, D.F.; Ernstoff, M.S.; Maranchie, J.K.; Parikh, R.A.; Friedland, D.; et al. Safety and activity of hydroxychloroquine and aldesleukin in metastatic renal cell carcinoma: A cytokine working group phase II study. J. Clin. Oncol. 2018, 36, 4573. [CrossRef]

63. El-Chemaly, S.; Taveira-Dasilva, A.; Goldberg, H.J.; Peters, E.; Haughey, M.; Bienfang, D.; Jones, A.M.; Julien-Williams, P.; Cui, Y.; Villalba, J.A.; et al. Sirolimus and autophagy inhibition in lymphangioleiomyomatosis: Results of a phase I clinical trial. Chest 2017, 151, 1302-1310. [CrossRef]

64. Haas, N.B.; Appleman, L.J.; Stein, M.; Redlinger, M.; Wilks, M.; Xu, X.; Onorati, A.; Kalavacharla, A.; Kim, T.; Zhen, C.J.; et al. Autophagy inhibition to augment mTOR inhibition: A phase I/II trial of everolimus and hydroxychloroquine in patients with previously treated renal cell carcinoma. Clin. Cancer Res. 2019, 25, 2080-2087. [CrossRef]

65. Zeh, H.J.; Bahary, N.; Boone, B.A.; Singhi, A.D.; Miller-Ocuin, J.L.; Normolle, D.P.; Zureikat, A.H.; Hogg, M.E.; Bartlett, D.L.; Lee, K.K.; et al. A randomized phase II preoperative study of autophagy inhibition with high-dose hydroxychloroquine and gemcitabine/nab-paclitaxel in pancreatic cancer patients. Clin. Cancer Res. 2020, 26, 3126-3134. [CrossRef] [PubMed]

66. Lockhart, A.C.; Bauer, T.M.; Aggarwal, C.; Lee, C.B.; Harvey, R.D.; Cohen, R.B.; Sedarati, F.; Nip, T.K.; Faessel, H.; Dash, A.B.; et al. Phase ib study of pevonedistat, a NEDD8-activating enzyme inhibitor, in combination with docetaxel, carboplatin and paclitaxel, or gemcitabine, in patients with advanced solid tumors. Investig. New Drugs 2019, 37, 87-97. [CrossRef] [PubMed]

67. Zhou, X.; Sedarati, F.; Faller, D.V.; Zhao, D.; Faessel, H.M.; Chowdhury, S.; Bolleddula, J.; Li, Y.; Venkatakrishnan, K.; Papai, Z. Phase I study assessing the mass balance, pharmacokinetics, and excretion of [ 14 C]-pevonedistat, a NEDD8-activating enzyme inhibitor in patients with advanced solid tumors. Investig. New Drugs 2021, 39, 488-498. [CrossRef] [PubMed]

68. Swords, R.T.; Coutre, S.; Maris, M.B.; Zeidner, J.F.; Foran, J.M.; Cruz, J.; Erba, H.P.; Berdeja, J.G.; Tam, W.; Vardhanabhuti, S.; et al. Pevonedistat, a first-in-class NEDD8-activating enzyme inhibitor, combined with azacitidine in patients with AML. Blood 2018, 131, 1415-1424. [CrossRef] [PubMed]

69. Bhatia, S.; Hamid, O.; Pavlick, A.C.; Mulligan, G.; Smith, P.G.; Pickard, M.D.; Shultz, M.; Walker, R.M.; Dezube, B.; O’Day, S. MLN4924, an investigational NEDD8-activating enzyme (NAE) inhibitor, in patients (pts) with metastatic melanoma: Results of a phase I study. J. Clin. Oncol. 2011, 29, 8529. [CrossRef]

70. Sekeres, M.A.; Watts, J.; Radinoff, A.; Sangerman, M.A.; Cerrano, M.; Lopez, P.F.; Zeidner, J.F.; Campelo, M.D.; Graux, C.; Liesveld, J.; et al. Randomized phase 2 trial of pevonedistat plus azacitidine versus azacitidine for higher-risk MDS/CMML or low-blast AML. Leukemia 2021, 35, 2119-2124. [CrossRef] 
71. Swords, R.T.; Erba, H.P.; DeAngelo, D.J.; Bixby, D.L.; Altman, J.K.; Maris, M.; Hua, Z.; Blakemore, S.J.; Faessel, H.; Sedarati, F.; et al. Pevonedistat (MLN4924), a First-in-Class NEDD8-activating enzyme inhibitor, in patients with acute myeloid leukaemia and myelodysplastic syndromes: A phase 1 study. Br. J. Haematol. 2015, 169, 534-543. [CrossRef]

72. Marinković, M.; Šprung, M.; Buljubasic, M.; Novak, I. Autophagy modulation in cancer: Current knowledge on action and therapy. Oxidative Med. Cell. Longev. 2018, 2018, 1-18. [CrossRef]

73. Kim, K.W.; Hwang, M.; Moretti, L.; Jaboin, J.J.; Cha, Y.I.; Lu, B. Autophagy upregulation by inhibitors of caspase-3 and mTOR enhances radiotherapy in a mouse model of lung cancer. Autophagy 2008, 4, 659-668. [CrossRef]

74. Xie, X.; White, E.P.; Mehnert, J.M. Coordinate autophagy and mTOR pathway inhibition enhances cell death in melanoma. PLoS ONE 2013, 8, e55096. [CrossRef]

75. Rubinsztein, D.C.; Codogno, P.; Levine, B. Autophagy modulation as a potential therapeutic target for diverse diseases. Nature reviews. Nat. Rev. Drug Discov. 2012, 11, 709-730. [CrossRef] [PubMed]

76. Halcrow, P.W.; Geiger, J.D.; Chen, X. Overcoming chemoresistance: Altering pH of cellular compartments by chloroquine and hydroxychloroquine. Front. Cell Dev. Biol. 2021, 9, 627639. [CrossRef] [PubMed]

77. Pellegrini, P.; Strambi, A.; Zipoli, C.; Hägg-Olofsson, M.; Buoncervello, M.; Linder, S.; De Milito, A. Acidic extracellular pH neutralizes the autophagy-inhibiting activity of chloroquine. Autophagy 2014, 10, 562-571. [CrossRef] [PubMed]

78. Varisli, L.; Cen, O.; Vlahopoulos, S. Dissecting pharmacological effects of chloroquine in cancer treatment: Interference with inflammatory signaling pathways. Immunology 2020, 159, 257-278. [CrossRef] [PubMed]

79. Wabitsch, S.; McVey, J.C.; Ma, C.; Ruf, B.; Kamenyeva, O.; McCallen, J.D.; Diggs, L.P.; Heinrich, B.; Greten, T.F. Hydroxychloroquine can impair tumor response to anti-PD1 in subcutaneous mouse models. iScience 2021, 24, 101990. [CrossRef]

80. Zou, Z.; Tao, T.; Li, H.; Zhu, X. mTOR signaling pathway and mTOR inhibitors in cancer: Progress and challenges. Cell Biosci. 2020, 10, 31. [CrossRef] 